\title{
High Gain and Reduced Switch Stress DC-DC Converter Topology for PV System
}

\author{
C.Srideepa ${ }^{1}$, S.Sathish Kumar ${ }^{2}$, R.Nagarajan ${ }^{3}$ \\ ${ }^{1}$ PG. Scholar, Department of Electrical and Electronics Engineering, Gnanamani College of Technology, \\ Namakkal, India \\ ${ }^{2}$ Assistant Professor, Department of Electrical and Electronics Engineering, Gnanamani College of \\ Technology, Namakkal, India \\ ${ }^{3}$ Professor, Department of Electrical and Electronics Engineering, Gnanamani College of Technology, \\ Namakkal, Tamilnadu, India
}

\begin{abstract}
:
This paper presents a new high step-up isolated DC-DC converter topology for photovoltaic system. The suggested configuration provides a converter with high voltage gain and reduced switch stress by using three coupled inductor with two hybrid voltage multiplier cell. The operation of the proposed converter is based on a charging capacitor with a single switch in its structure. A passive clamp circuit composed of capacitors and diodes is employed in the converter structure for lowering the voltage stress on the power switch as well as increasing the voltage gain of the converter. Since the voltage stress is low in the provided topology, a switch with a small ON-state resistance can be used. As a result, the losses are decreased and the efficiency is increased. The design of DC-DC boost converter is also discussed in detail. Simulation of DC-DC converter is performed in MATLAB/Simulink and the result are verified.
\end{abstract}

Keywords: IBC-Interleaved Boost Converter, CI-Coupled Inductor, VMC-Voltage Multiplier Cell SCSwitched Capacitor

\section{Introduction}

The renewable energy technology has undergone a substantial development in the last three decades. Photovoltaic (PV) system is promising and one of the fastest growing renewable energy sources. The proposal uses a voltage boosting cell associated with a coupled-inductor in order to achieve the high stepup voltage gain [1]. Differently from the high gain converters frequently proposed in the literature, this one presents inherent characteristic of current source at the output. The values suggested could be used to modify the function parameters for the scenarios considered, and DC converter is used between the PV module and inverter to minimize size of the transformer connected at the AC grid side [2]. The overall performance of such a system depends mainly on the efficiency of power conversion stages. Hence, selecting an appropriate high gain DC-DC converter is critical

In conventional boost DC-DC converter, diode reverse recovery problem and switch stress at extreme duty ratios restrict the practical voltage gain. Though a cascaded boost converter offers higher conversion ratio, presence of more components limits its operating efficiency [3]. The Magnetically coupled converters like fly back, push pull and full bridge converter can provide the required voltage gain by properly choosing turns ratio of transformer. Unfortunately, the leakage inductance of the magnetic element causes additional voltage stress and incremental losses on the switch. Without using a transformer, several methods to enhance the voltage gain include using voltage multiplier cell (VMC), coupled inductor (CI) and switched capacitor (SC) networks [4].

The step up converters provide the required voltage gain but their power handling capability is limited by their component count. Three phase interleaved boost converter (IBC) based on coupled inductors and VMC is proposed. The three switches present in the operated with a uniform phase shift between them. This helps to reduce the input current ripple [5]. Two simple inductors are replaced by coupled inductors to increase the voltage gain and handle higher power. The main features of this converter are high voltage gain, low voltage and current stress on the switches, low input current high power handling capability. Recently the use of step- 
up DC-DC converters with high voltage ratio has been increased. That is due to the growing usage of this type of converters in a wide range of applications such as fuel cell stacks (FC), photovoltaic (PV) cells, uninterruptable power supplies (UPS), etc. In these sorts of applications high step-up converters are used to convert the low level varying primary voltage to the desired regulated high voltage output [6]-[8].

The conventional boost converter is not applicable in power sector for high voltage gain due to high switching losses. The duty cycle of an isolation transformer, which is connected in openloop condition of the controlled isolated $\mathrm{dc}-\mathrm{dc}$ converter, is fixed. In the resultant of soft switching of all the power semiconductor switches can be always achieved by utilizing the leakage inductance [9]-[11]. This paper proposed a dc-dc boost converter topology based on three winding coupled inductor and diode-capacitor technology for high step-up, high power density and high efficiency conversion, which adopts a single switch and two series hybrid voltage multiplier cells. Moreover, two identical passive regenerative snubbers are used for absorbing the energy of stray inductance, clamping the voltage spike of the main switch [12]-[14].

you submit your paper print it in two-column format, including figures and tables. In addition, designate one author as the "corresponding author". This is the author to whom proofs of the paper will be sent. Proofs are sent to the corresponding author only [15]-[17].

\section{Operating Principle of the Proposed Converter}

The equivalent circuit of the proposed converter topology is shown in Figure 1, in which a three winding coupled inductor ( $\mathrm{T}$ ) can be modeled by a magnetizing inductor $\mathrm{Lm}$, a leakage inductance $\mathrm{L}_{\mathrm{k}}$, and an ideal transformer with primary winding $\mathrm{N}_{1}$ and two secondary windings $\mathrm{N}_{2}$ and $\mathrm{N}_{3}$.

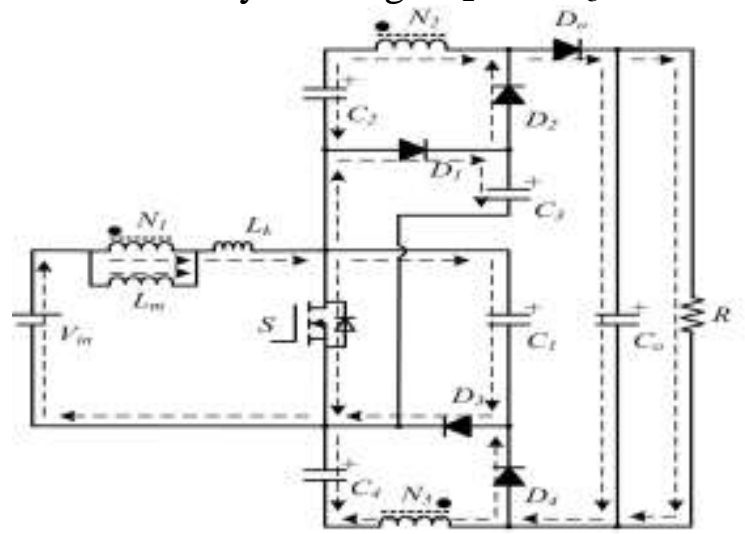

Figure 1: Circuit Diagram of the Proposed Converter
The two parallel passive regenerative snubbers are composed of the diode $\mathrm{D}_{1}$ and capacitor $\mathrm{C}_{3}$, the diode $\mathrm{D}_{3}$ and capacitor $\mathrm{C}_{1}$, through which the energy stored in the leakage inductor, can be recycled effectively. Also, the voltage across the main switch $S$ is clamped to a lower level. Thus, the efficiency can be improved greatly. In addition, two hybrid voltage multiplier cells are respectively composed of secondary side windings $\mathrm{N}_{2}$ and $\mathrm{C}_{2}, \mathrm{~N}_{3}$ and $\mathrm{C}_{4}$. When the main switch is on, the magnetizing inductor and two capacitors in voltage multiplier cells are charged, and the capacitor $\mathrm{C}_{\mathrm{o}}$ provides energy to the load. When the main switch is off, the primary side and secondary sides of the coupled inductor, two capacitors $\mathrm{C}_{2}$ and $\mathrm{C}_{4}$, and input $\mathrm{dc}$ source are connected in series for transferring energy to the load. Therefore, the proposed converter can achieve high-voltage gain in appropriate duty cycles and low turns ratios.

The operating principles of the proposed converter for continuous conduction mode (CCM) and discontinuous conduction mode (DCM) are presented as follows [18]-[20].

\subsection{CCM Operation}

This section presents the operation principle of CCM, and explains the power flow state of each mode. The operation process is divided into six modes during one switching period. The Figure 2 shows the waveforms of the proposed converter at CCM. To simplify the circuit analysis of the proposed converter, the following conditions are assumed [21]-[23]:

1. The capacitors $\mathrm{C}_{1}, \mathrm{C}_{2}, \mathrm{C}_{3}, \mathrm{C}_{4}$ and $\mathrm{C}_{\mathrm{o}}$ are large enough to reasonably neglect the voltage ripples.

2 . The power switch and diodes are ideal, except for $D_{0}, D_{2}$ and $D_{4}$. Because the reverse-recovery problems of diodes $\mathrm{D}_{0}, \mathrm{D}_{2}$ and $\mathrm{D}_{4}$ will be discussed, and all forward voltage drops on them are ignored.

3 . The coupling coefficient of the coupled inductor $k$ is equal to $\mathrm{L}_{\mathrm{m}} /\left(\mathrm{L}_{\mathrm{m}}+\mathrm{L}_{\mathrm{k}}\right)$, and the turns ratio $\mathrm{n}=\mathrm{N}_{2} / \mathrm{N}_{1}$ $=\mathrm{N}_{3} / \mathrm{N}_{1}$.

Mode I $\left[\mathrm{t}_{0}-\mathrm{t}_{1}\right]$ : At $\mathrm{t}=\mathrm{t}_{0}$, the switch $\mathrm{S}$ is turned on nearly zero-current-switching (ZCS) due to the role of leakage inductance, which is helpful for alleviating the switching loss. During this short time interval, $\mathrm{D}_{1}, \mathrm{D}_{2}, \mathrm{D}_{3}$, and $\mathrm{D}_{4}$ are turned off, and $\mathrm{D}_{0}$ still remains on state. The current flow path is shown in Figure 3 (a). The magnetizing inductor $\mathrm{L}_{\mathrm{m}}$ along with $\mathrm{C}_{2}$ winding $\mathrm{N}_{2}$ and $\mathrm{N}_{3}$, the leakage inductance $\mathrm{L}_{\mathrm{k}}$ is charged by and $\mathrm{C}_{4}$ continues to release energy to the output through the source Vin. Therefore, magnetizing inductor current $\mathrm{i}_{\mathrm{Lm}}$, the secondary 
winding currents $i_{\mathrm{N} 2}$ and $i_{\mathrm{N} 3}$ are decreased linearly, and the leakage inductance current $i_{L k}$ is increased linearly. The current ids through the main switch $\mathrm{S}$ is increased linearly [24]. This mode ends when the current flowing through winding $\mathrm{N}_{2}$ and winding $\mathrm{N}_{3}$ falls to zero at $\mathrm{t}=\mathrm{t}_{1}$.

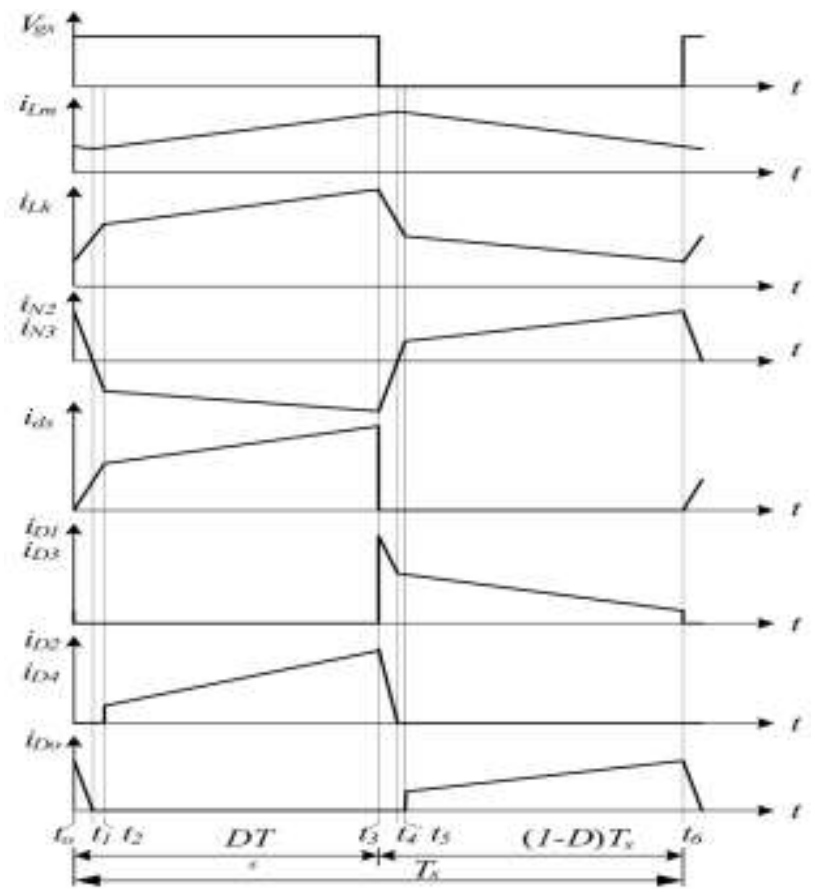

Figure 2: Waveforms of the Proposed Converter at CCM

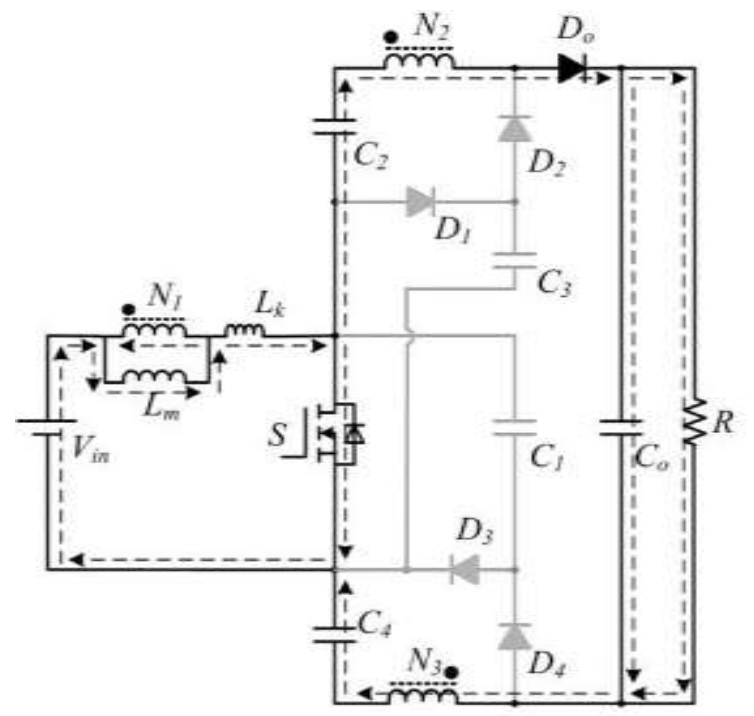

Figure 3 (a): CCM Mode I

Mode II $\left[\mathrm{t}_{1}-\mathrm{t}_{2}\right]$ : From the time $\mathrm{t}=\mathrm{t}_{1}$, the equivalent junction capacitor $C_{o}$ of the output diode $D_{o}$ begins to release the stored charge to the leakage inductance of secondary winding and capacitors $\mathrm{C}_{2}$ and $\mathrm{C}_{4}$, and the reverse recovery energy of the output diode $\mathrm{D}_{\mathrm{o}}$ is recycled [25]. The current flowing through winding $\mathrm{N}_{2}$ and winding $\mathrm{N}_{3}$ is increased inversely, and the current flow path is shown in Figure 3 (b). This time interval is extremely short, and the diodes $\mathrm{D}_{2}$ and $\mathrm{D}_{4}$ start to conduct at $\mathrm{t}=\mathrm{t}_{2}$.

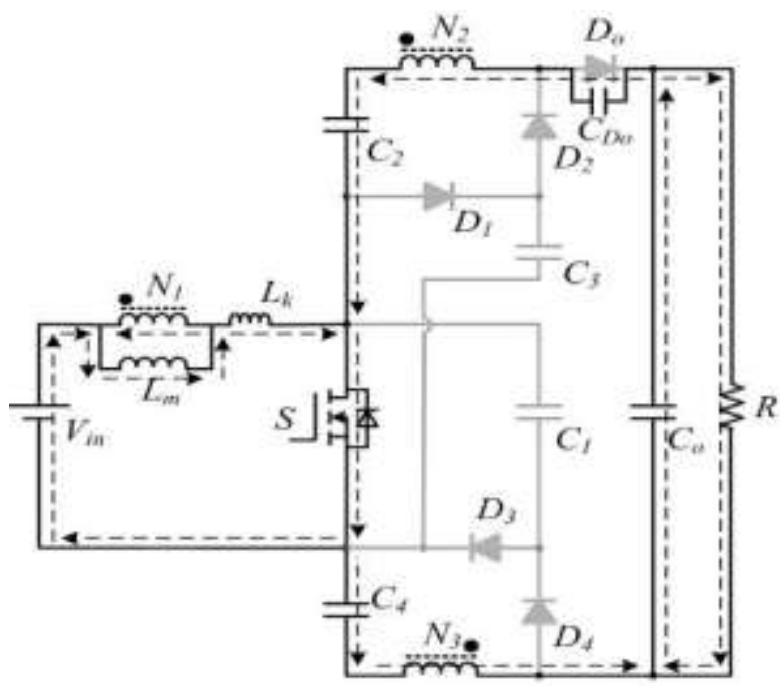

Figure 3 (b): CCM Mode II

Mode III $\left[\mathrm{t}_{2}-\mathrm{t}_{3}\right]$ : During this interval, the secondary voltage $\mathrm{VN}_{2}$ and the clamped capacitor voltage $\mathrm{VC}_{3}$ are connected in series to charge the double-voltage capacitor $\mathrm{C}_{2}$ through the switch and the rectifier diode $\mathrm{D}_{2}$. Simultaneously, the secondary voltage $\mathrm{VN}_{3}$ and the clamped capacitor voltage $\mathrm{VC}_{1}$ are connected in series to charge the double-voltage capacitor $\mathrm{C}_{4}$ through the switch and the rectifier diode $\mathrm{D}_{4}$. The magnetizing inductor $\mathrm{L}_{m}$ and leakage inductor $\mathrm{L}_{\mathrm{k}}$ are charged by the source $\mathrm{V}_{\mathrm{in}}$. Therefore, the current $i_{L m}$ and the leakage inductance current $i_{L k}$ are increased linearly. Meanwhile, the output capacitor $\mathrm{C}_{\mathrm{o}}$ provides its energy to the load [26]. The current flow path is shown in Figure 3(c).

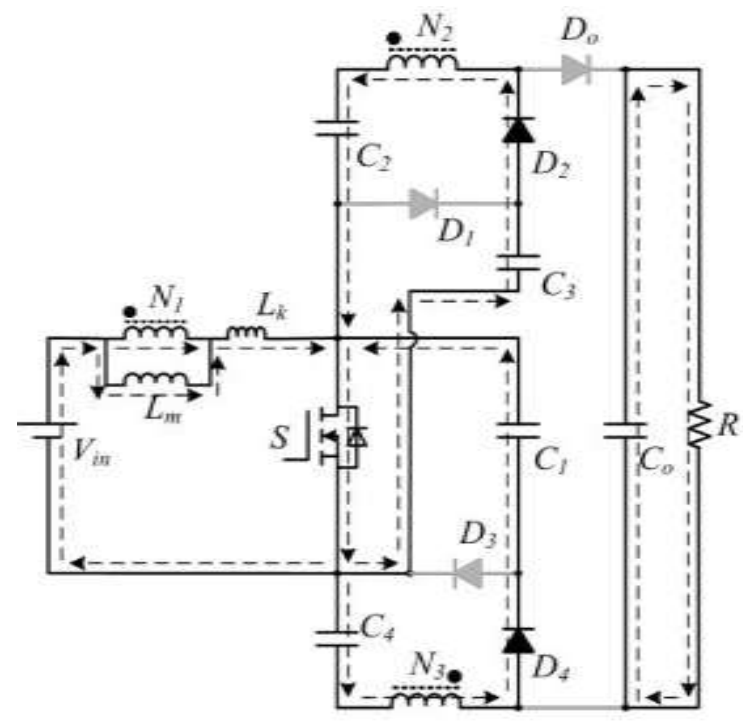

Figure 3 (c): CCM Mode III

Mode IV $\left[\mathrm{t}_{3}-\mathrm{t}_{4}\right]$ : At the time $\mathrm{t}=\mathrm{t}_{3}$, the switch $\mathrm{S}$ is turned off. On the one hand, the input source $V_{\text {in }}$ is series connected with $\mathrm{N}_{1}$ and $\mathrm{L}_{\mathrm{K}}$ to charge clamped capacitors $C_{1}$ and $C_{3}$ through diodes $D_{1}$ and $D_{3}$. The energy of leakage inductance is recycled and the current $i_{L k}$ is decreased linearly [27]. On the other hand, the secondary winding current $\mathrm{i}_{\mathrm{N} 2}\left(\mathrm{i}_{\mathrm{N} 3}\right)$ are decreased rapidly since the opposite direction of the voltage of the winding $\mathrm{N}_{2}$ and $\mathrm{N}_{3}$. At the time $\mathrm{t}=\mathrm{t}_{4}$, 
the winding current $i_{\mathrm{N} 2}\left(i_{\mathrm{N} 3}\right)$ decays to zero. The current flow path is shown in Figure 3(d).

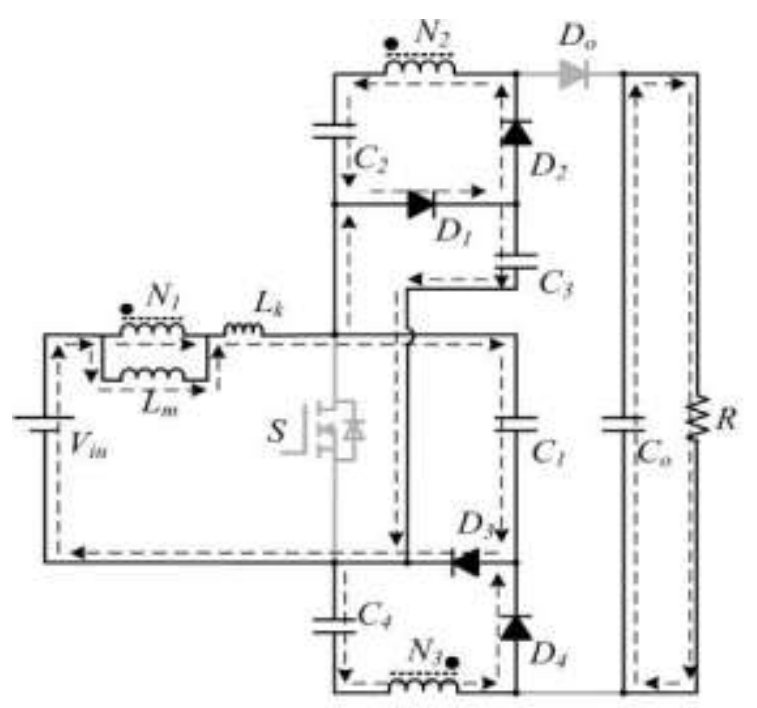

Figure 3 (d): CCM Mode IV

Mode $\mathrm{V}\left[\mathrm{t}_{4}-\mathrm{t}_{5}\right]$ : During this extremely short period, the equivalent junction capacitor $\mathrm{CD}_{2}$ of the output diode $\mathrm{D}_{2}$ and the equivalent junction capacitor $\mathrm{CD}_{4}$ of the output diode D4 release energy, this is recycled [28]. The magnetizing inductor $\mathrm{Lm}$ begins to be discharged to capacitors $\mathrm{C}_{1}$ and $\mathrm{C}_{3}$, and the current flow path is shown in Figure 3 (e). Meanwhile, the output capacitor Co provides its energy to load R.

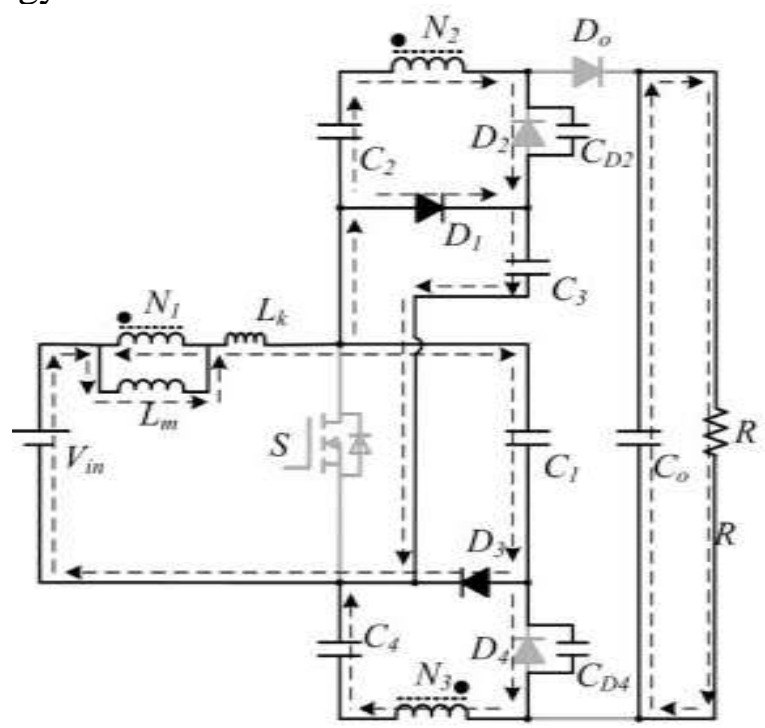

Figure 3 (e): CCM Mode V

Mode VI $\left[\mathrm{t}_{5}-\mathrm{t}_{6}\right]$ : At $\mathrm{t}=\mathrm{t}_{5}$, the diode $\mathrm{D}_{\mathrm{o}}$ is conducted. The current flow path is shown in Figure 3 (f). The leakage inductor, two capacitors $\mathrm{C}_{2}$ and $\mathrm{C}_{4}$, the magnetizing inductor and input source $\mathrm{V}_{\text {in }}$ are series discharged to the output. The clamped capacitors $C_{1}$ and $\mathrm{C}_{3}$ are parallel charged by leakage inductance $\mathrm{L}_{\mathrm{k}}$

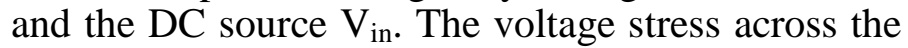
switch $S$ is clamped to low voltage level. The magnetizing inductor current $i_{L m}$, leakage inductance current $i_{L k}$, diodes current $i_{D 1}$ and $i_{D 3}$ are decreased linearly [29]. Since the leakage inductance is smaller and the $i_{L k}$ current decreases faster than that of the magnetizing inductor current $i_{L m}$, the secondary winding currents $i_{\mathrm{N} 2}$ and $i_{\mathrm{N} 3}$ are increase linearly according to the principle of idea transformer. When the switch $\mathrm{S}$ is turned on again, this mode is ended.

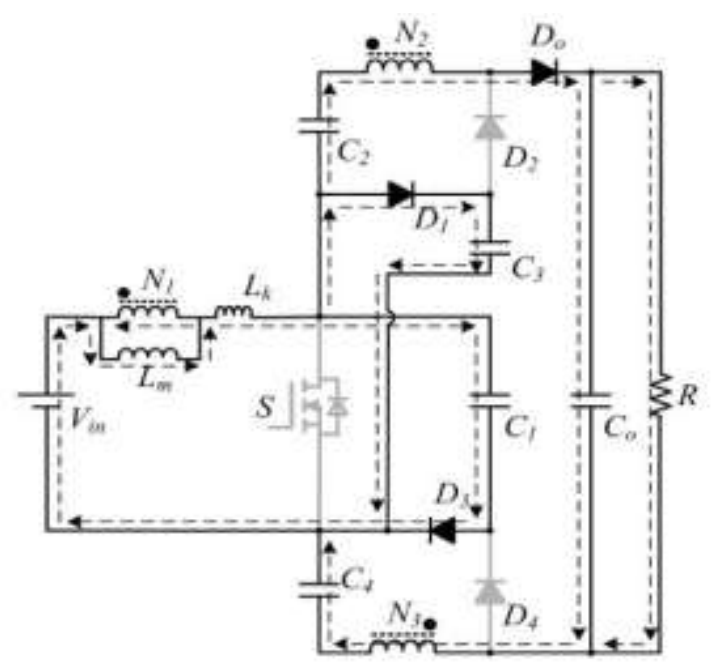

Figure 3 (f): CCM Mode VI

\section{Performance Analysis}

\subsection{Voltage Gain}

To simplify the steady-state analysis, only mode-III and mode-IV are taken into account, and other modes occupying extremely short time are ignored. When the switch $S$ is turned on, the following equations can be obtained from Fig.3(c).

$$
\begin{aligned}
& V_{s 1}^{\mathrm{nt}}=\frac{L_{\mathrm{c}}}{L_{s n}+L_{4}}=k V_{n}
\end{aligned}
$$

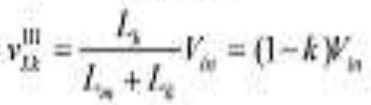

$$
\begin{aligned}
& v_{s 2}^{\mathrm{III}}=v_{N 3}^{\mathrm{III}}=n v_{s \mathrm{I}}^{\mathrm{III}}=n k V_{n n}
\end{aligned}
$$

Where $k$ is the coupling coefficient of the coupled inductor, and $n$ is the turn's ratio of the coupled inductor. When the switch $S$ is turned off, the coupled inductor and the DC source $\mathrm{V}_{\text {in }}$ are in series connected to discharged the outlet side as shown in Fig.3 (f). By applying voltage-second balance principle on $N_{1}, N_{z}, N_{3}$ and $L_{\mathrm{k}}$, the voltage $\mathrm{V}_{\mathrm{N} 1}, \mathrm{~V}_{\mathrm{N} 2}$, $\mathrm{V}_{\mathrm{N} 3}$, and $\mathrm{V}_{\mathrm{Lk}}$ are found as follows [30]:

$$
\begin{gathered}
v_{N 1}^{\mathrm{u}}=\frac{D k}{1-D} V_{w} \\
v_{N 2}^{\mathrm{U}}=v_{N 1}^{\mathrm{U}}=\frac{n D k}{1-D} V_{s} \\
v_{L k}^{\mathrm{V}}=\frac{D(1-k)}{1-D} V_{s,}
\end{gathered}
$$

The voltage of capacitors $C_{1}, C_{2}, C_{3}$ and $C_{4}$ can be written as: 


$$
\begin{aligned}
& V_{C 1}=V_{c 3}=V_{s+}+v_{N 1}^{n}+V_{r k}^{\mathrm{V}}=\frac{1}{1-D} V_{i n} \\
& V_{c 2}=V_{C 4}=V_{C 1}+V_{N 3}^{\mathrm{II}}=\left(n k+\frac{1}{1-D}\right) V_{w}
\end{aligned}
$$

\subsection{Voltage Stresses on Components}

The voltage stress of the main switch $\mathrm{S}_{\text {and }} \mathrm{D}_{1}, \mathrm{D}_{3}$ are represented as

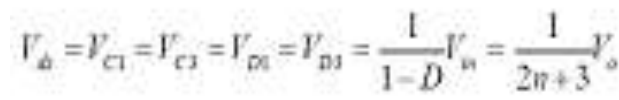

According to the aforementioned description of CCM modes, the voltage stress of diodes $D 2, D 4$, and $D o$ are given as

$$
\begin{gathered}
V_{D 2}=V_{D i}=\frac{1+n}{1-D} Y_{L}=\frac{n+1}{2 n+3} Y_{i} \\
V_{D u}=\frac{2 n+1}{1-D} V_{n}=\frac{2 n+1}{2 n+3} Y_{4}
\end{gathered}
$$

For demonstrating the performance of the proposed converter, the proposed converter is compared with other three winding coupled inductor converters in [25] and [30] as shown table 1. It can be found that the voltage of the proposed converter is highest and the voltage stress on switch is lowest under the same duty cycle D and the same turns ratio $\mathrm{n}$ designed as less than 2 . Besides, the quantities of diodes and capacitors are the least as converter introduced in [25], which is conducive to reducing the cost.

Table 1 Performance Comparison of Similar Converters

\begin{tabular}{|c|c|c|c|}
\hline $\begin{array}{c}\text { High step-tup } \\
\text { converter }\end{array}$ & $\begin{array}{c}\text { Converter in } \\
{[25]}\end{array}$ & $\begin{array}{c}\text { Converter in } \\
{[30]}\end{array}$ & $\begin{array}{c}\text { Proposed } \\
\text { converter }\end{array}$ \\
\hline Voltage gain & $\frac{2 n+2-n D}{1-D}$ & $\frac{3 n+2-n D}{1-D}$ & $\frac{2 n+3}{1-D}$ \\
\hline $\begin{array}{c}\text { Voltage stress on } \\
\text { switch }\end{array}$ & $\frac{V_{0}}{2 n+2-n D}$ & $\frac{V_{0}}{3 n+2-n D}$ & $\frac{V_{0}}{2 n+3}$ \\
\hline $\begin{array}{c}\text { Quantities of } \\
\text { diodes }\end{array}$ & 5 & 6 & 5 \\
\hline $\begin{array}{c}\text { Quantities of } \\
\text { cupacitors }\end{array}$ & 5 & 6 & 5 \\
\hline $\begin{array}{c}\text { Quantities of } \\
\text { windings }\end{array}$ & 3 & 3 & 3 \\
\hline
\end{tabular}

\subsection{Turns Ratio of Coupled Induction Selection}

In the proposed converter, the coupled inductor is operated as both flyback and forward converters; therefore, the coupled inductor should be designed as a flyback transformer. The turn's ratio of the coupled inductor has an influence on the switch duty cycle
[31]-[33], the voltage gain, and the voltage stress of power devices. The turn's ratio can be depicted by

$$
n=\frac{V_{s}}{2 V_{i n}}(1-D)-\frac{3}{2}
$$

The input voltage and the output voltage are determined by the specific application. Hence, if the duty cycle is chosen, the turn's ratio of the coupled inductor can be carried out easily, and then the voltage stress of power devices can be calculated. Generally, the duty cycle is less than 0.7 in order to decrease conduction loss. On the contrary, if the duty cycle is too small, the volume of the coupled inductor will be larger due to the bigger turn's ratio. As a result, a compromise should be made considering the duty cycle and the turns ratio under given voltage gain [34].

\subsection{Coupled Inductor Design}

In theory, the proposed converter will be operated in CCM (continuous conduction mode) if the $L m$ is higher than $L m B$, and it will be operated in DCM (discontinuous conduction mode) when the $L m$ is smaller than $L m B$.

$$
L_{\mathrm{m} \delta}=\frac{D(1-D)^{2} R T_{i}}{2(2 n+3)^{2}}
$$

\subsection{Main Switch and Diodes Selection}

In practice, voltage spike will occur when the main switch is turned off owing to the leakage inductance of the coupled inductor and parasitic capacitor. In addition, the spike voltage also can be caused because of the stray inductance and capacitance existing in printed circuit board. Hence, considering above-mentioned factor, the voltage and current ratings of the chosen active devices are usually larger than $150 \%$ of the calculated value [35].

\subsection{Capacitor Selection}

The voltage ripple of capacitors depends on the value of capacitors. In order to restrain the voltage ripple to an acceptable range, the minimum capacitance should be calculated. According to $\Delta Q=C V C=I C T$, (35) and (36) can be used to estimate the capacitance of capacitors, in which Vo is the output voltage, $V_{\mathrm{C}}$ and $V_{\mathrm{Co}}$ represent the maximum acceptable voltage ripple on capacitors $C_{1} \sim C_{4}$ and $C_{0}, f \mathrm{~s}$ is the switching frequency, and $R$ is the load.

$$
\begin{aligned}
& C \geq \frac{V_{s}}{\Delta V_{c} R f,} \\
& C_{0}=\frac{D V_{a}}{\Delta V_{c_{0}} R f .}
\end{aligned}
$$


Considering the equivalent series resistor (ESR), a fraction of power will be dissipated when the converter is in operation. The ESR of an aluminum electrolytic capacitor will be smaller as the capacitance increases. Therefore, the capacitance is usually selected to be much larger than the calculated value.

\section{Result Analyzes}

To reconfirm the viability and accurate performance of the proposed high step-up dc-dc converter, some simulation results through MATLAB/Simulink software and a built prototype in the laboratory to verify the performance of the proposed converter. In the MATLAB/Simulink platform, the voltage waveform for input and output of the proposed converter are shown. Figure 4 shows the simulation results of the proposed converter with an output voltage of $400 \mathrm{~V}$.
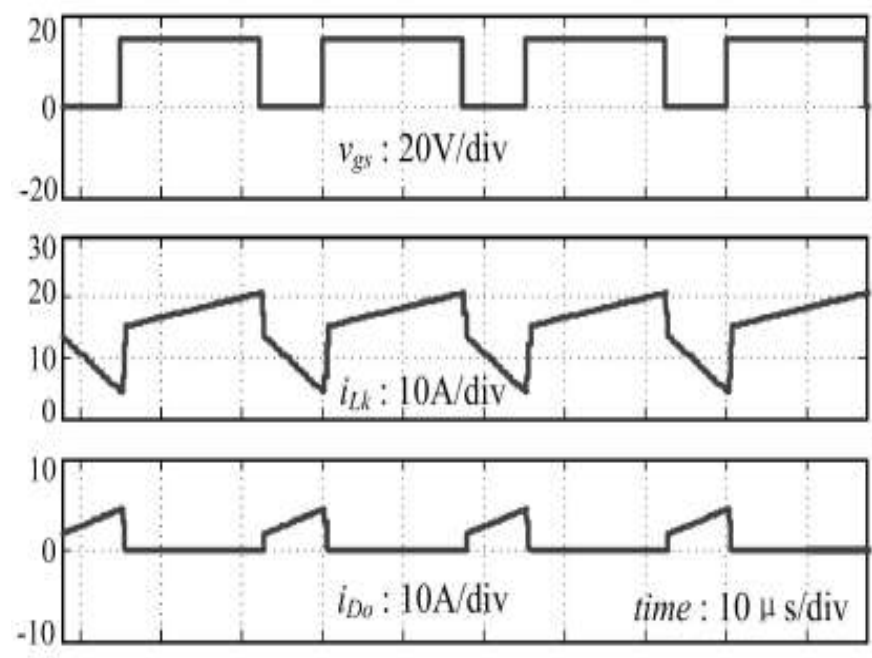

Figure 4 (a): Simulated Results of Vgs, $i_{\text {LK }}$ and $i_{\text {Do }}$
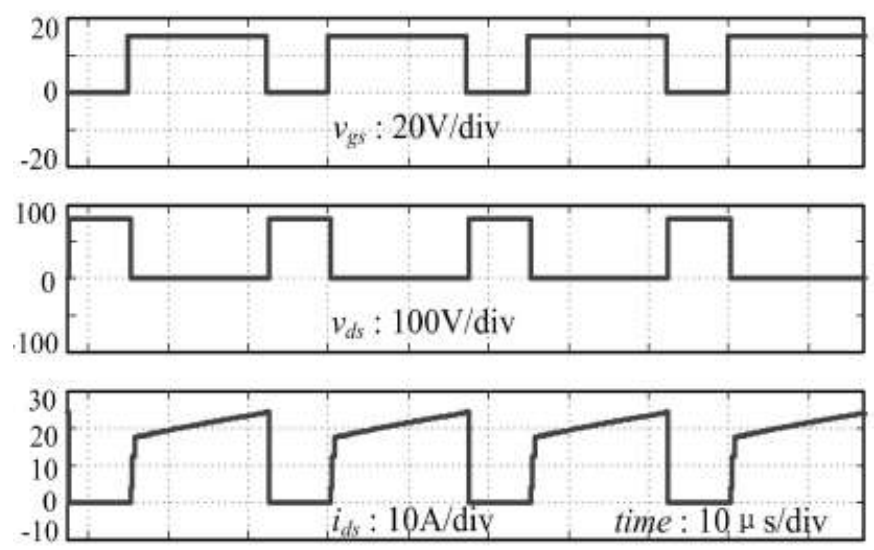

Figure 4 (b): Simulated Results of $\mathrm{V}_{\mathrm{gs}}, \mathrm{V}_{\mathrm{ds}}$ and $\mathrm{i}_{\mathrm{ds}}$

The electric specifications and circuit components are selected as $V_{\text {in }}=25 \mathrm{~V}, \mathrm{~V}_{\mathrm{O}}=400 \mathrm{~V}, \mathrm{f}_{\mathrm{S}}=40 \mathrm{KHz}$, $\mathrm{N}_{1}: \mathrm{N}_{2}: \mathrm{N}_{3}=1: 1: 1, \quad \mathrm{C}_{1}=\mathrm{C}_{3}=100 \mu \mathrm{F}, \quad \mathrm{C}_{2}=\mathrm{C}_{4}=220 \mu \mathrm{F}$, Figure 4(a) gives the simulated results of driving signal of switch $S$ and the input current $i_{L k}$, and the current $\mathrm{i}_{\text {Do }}$ through the diode $\mathrm{D}_{\mathrm{O}}$. It shows that the simulated results of voltage of the converter are operated in CCM and the reverse-recovery problem of output diode is alleviated. Figure 4(b) illustrates the simulated results of the voltage and current stress across switch $\mathrm{S}$. One can see that the voltage stress is far lower than output voltage, and the switch $\mathrm{S}$ is turned on with zero current nearly due to the leakage inductor of coupled inductor. Figure 5 shows the PWM generator signal for various duty cycles.

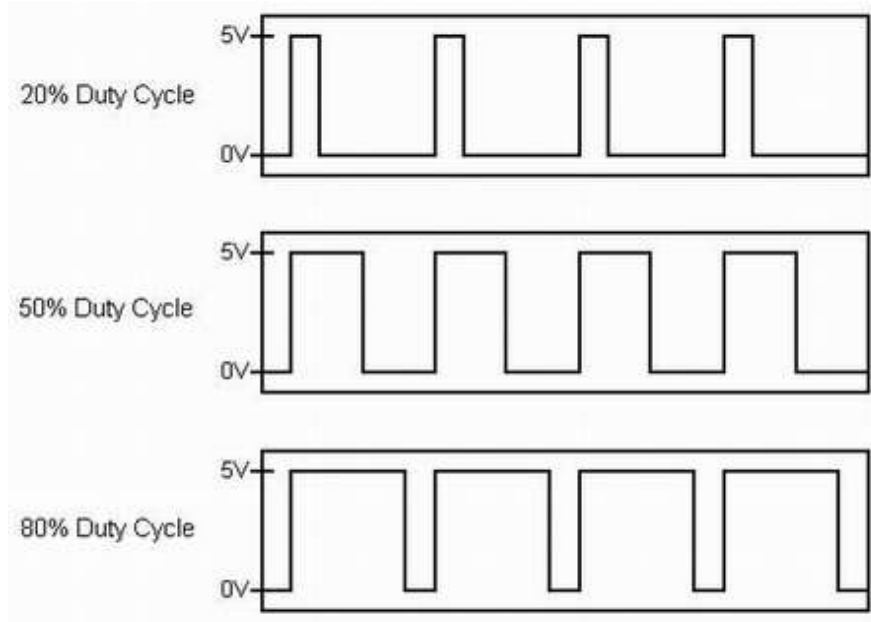

Figure 5: PWM Generator Signal for Various Duty Cycles

\section{Conclusion}

This paper proposes a novel DC-DC boost converter structure by using a single switch, a three- winding coupled inductor and two hybrid multiple voltage cells. The two multiple voltage cells are parallel charged and discharged series. Thus, the presented topology can provide very high voltage gain under appropriate duty cycle and turns ratio. Meantime, the operation analysis and design for the converter becomes quite simple since the two multiple voltage units are identical. Moreover, the voltage stress of the main switch $S$ is clamped at a level far less than output voltage, so the power switch $S$ with low $R d s($ on) can be selected to improve the efficiency. The steady- state analysis of the converter is discussed in detail. The simulated results verify the good performance of proposed converter.

\section{References.}

[1] Chiba, K. Kiyota, N. Hoshi, M. Takemoto, and S. Ogasawara,"Development of a Rare-Earth-Free SR Motor With High Torque Density for Hybrid Vehicles," IEEE Trans. Energy Convers., vol. 30, no. 1, pp. 175-182, 2015.

[2] R.Nagarajan and M,Saravanan, "Performance Analysis of Multicarrier PWM Strategies for Cascaded Multilevel Inverter," European Journal of Scientific Research (EJSR), Vol.92 No.4, pp. 608-625, Dec. 2012. 
[3] B. K. Bose, "Global Warming: Energy, Environmental Pollution, and the Impact of Power Electronics," IEEE Ind. Electron. Mag., vol. 4, no. 1, pp. 6-17, 2010.

[4] R.Nagarajan and M,Saravanan, "A Carrier Based Pulse Width Modulation Control Strategies for Cascaded Multilevel Inverter," International Review on Modeling and Simulations (IRMOS), Vol 6.No1, pp-8-19, Feb. 2013.

[5] Liu, and J. Lai, "Low Frequency Current Ripple Reduction Technique With Active Control in a Fuel Cell Power System With Inverter Load," IEEE Trans. Power Electron., vol. 22, no. 4, pp. 1429-1436, 2007.

[6] R.Nagarajan and M, Saravanan, "Comparison of PWM Control Techniques for Cascaded Multilevel Inverter" International Review of Automatic control (IRACO), Vol.5, No.6, pp. 815-828. Nov. 2012.

[7] G. Vidhya Krishnan, R.Nagarajan, T. Durka, M.Kalaiselvi, M.Pushpa and S. Shanmuga priya, "Vehicle Communication System Using Li-Fi Technology," International Journal of Engineering And Computer Science (IJECS), Volume 6, Issue 3, pp. 20651-20657, March 2017.

[8] F. Yang, Q. Sun, Q. Han, and Z. Wu., "Cooperative Model Predictive Control for Distributed Photovoltaic Power Generation Systems," IEEE Journal of Emerging and Selected Topics in Power Electronics, vol. 4, no. 2, pp. 414-420,2016.

[9] M.Dharani Devi and R.Nagarajan, "Implementation of Different PWM Control Strategies for Cascaded MLI," Journal of Network Communications and Emerging Technologies (JNCET), Volume 7, Issue 7, pp. 49- 55, July-2017.

[10]R.Prabhu, R.Nagarajan, N.Karthick and S.Suresh, "Implementation of Direct Sequence Spread Spectrum Communication System Using FPGA," International Journal of Advanced Engineering, Management and Science (IJAEMS), Vol-3.Issue-5, pp. 488-496, May. 2017

[11]R. Banupriya, R.Nagarajan, M.Malarvizhi and M.Dharani Devi, "Multicarrier - Based PWM Control Strategies for Five - Level CMLI." Journal of Network Communications and Emerging Technologies (JNCET), Vol. 7, Issue 11, November - 2017, pp. 33-39.

[12]M.Dharani Devi, M.Malarvizhi and R.Nagarajan, "Development of Multicarrier
SPWM Techniques for Cascaded MLI." International Journal of Computational Engineering Research (IJCER), Vol. 7, Issue 10, October 2017, pp. 44-52.

[13]J.Chandramohan,

R.Nagarajan,

K.Satheeshkumar, N.Ajithkumar, P.A.Gopinath and S.Ranjithkumar, "Intelligent Smart Home Automation and Security System Using Arduino and Wi-fi," International Journal of Engineering And Computer Science (IJECS), Volume 6, Issue 3, pp. 20694-20698, March, 2017.

[14]H. Liu, X. Huang, L. Tan, J. Guo, and W. Wei., "Switching Control Optimization Strategy of Segmented Transmitting Coils for On-road Charging of Electrical Vehicles," IET Power Electron., vol. 9, no. 11, pp. 2282-2288, 2016.

[15]K. Anandhi and Dr. R. Nagarajan, "MutexHeart: Fail Safe Dual Chamber Cardiac Pacemaker Device with Rate Responsive Control and Cryptographic Security," IJSRDInternational Journal for Scientific Research \& Development. Vol. 3, Issue- 2, pp. 489-493, 2015.

[16]H. Rudnick, "Evolution of Energy: Global Developments and Challenges," IEEE Power Energy Mag., vol. 10, no.3, pp. 12-19, 2012.

[17]J.Chandramohan, R.Nagarajan, M.Ashok kumar, T.Dineshkumar, G.Kannan and R.Prakash, "Attendance Monitoring System of Students Based on Biometric and GPS Tracking System," International Journal of Advanced Engineering, Management and Science (IJAEMS), Vol-3.Issue-3, pp. 241-246, Mar. 2017.

[18]K. Jin, X. Ruan, M. Yang, and M. Xu, "A Hybrid Fuel Cell Power System," IEEE Trans. Ind. Electron., vol. 56, no. 4, pp. 1212-1222, 2009.

[19]R Rameshkumar and R Nagarajan, "Sine Multicarrier SPWM Technique for Seven Level Cascaded Inverter," CiiT-Programmable Device Circuits and Systems. Vol. 5, Issue- 6, 2013.

[20]Dr.R.Nagarajan,

S.Sathishkumar,

K.Balasubramani, C.Boobalan, S.Naveen and N.Sridhar. "Chopper Fed Speed Control of DC Motor Using PI Controller," IOSR- Journal of Electrical and Electronics Engineering (IOSRJEEE), Volume 11, Issue 3, Ver. I, pp. 65-69, May - Jun. 2016.

[21]R.Nagarajan and M,Saravanan "Staircase Multicarrier SPWM Technique for Nine Level Cascaded Inverter," 2013 International 
Conference on Power, Energy and Control (ICPEC), IEEE Press, pp-668-675. 2013.

[22]Lion M.Tolbert and Thomas.G.Habetler, "Novel Multi Level Inverter Carrier Based PWM methods", IEEE IAS, 1998, pp 1424-1431.

[23]N.Karthick, R.Nagarajan, S.Suresh and R.Prabhu, "Implementation of Railway Track Crack Detection and Protection," International Journal Of Engineering And Computer Science (IJECS), Volume 6, Issue 5, May 2017, pp. 21476-21481, DOI: 10.18535/ijecs/v6i5.47

[24]M.Padmavathi and R.Nagarajan, "Smart Intelligent ATM Using LABVIEW," International Journal of Emerging Technologies in Engineering Research (IJETER), Volume 5, Issue 5, pp. 41- 45, May-2017.

[25]R.Nagarajan and M, Saravanan. "Performance Analysis of a Novel Reduced Switch Cascaded Multilevel Inverter," Journal of Power Electronics, Vol.14, No.1, pp. 48-60, Jan.2014.

[26]S.Sathishkumar, R.Nagarajan, R.Yuvaraj, M. Sridhar and M.Elangovan, "Implementation of Pwm Technique for Integrated High Gain," IOSR Journal of Engineering (IOSRJEN), Vol. 08, Issue 3, PP. 59-66, March - 2018.

[27]R.Nagarajan, S.Sathishkumar, S.Deepika, G.Keerthana, J.K.Kiruthika and R.Nandhini, "Implementation of Chopper Fed Speed Control of Separately Excited DC Motor Using PI Controller", International Journal of Engineering And Computer Science (IJECS), Volume 6, Issue 3, pp. 20629-20633, March, 2017.

[28]R.Nagarajan, R.Yuvaraj, V.Hemalatha, S.Logapriya, A.Mekala and S.Priyanga, "Implementation of PV - Based Boost Converter Using PI Controller with PSO Algorithm," International Journal of Engineering And Computer Science (IJECS), Volume 6, Issue 3, pp. 20479-20484, March, 2017.

[29]Ms. C. Hemalatha, Mr. R. Nagarajan, P. Suresh, G. Ganesh Shankar and A. Vijay, "Brushless DC Motor Controlled by using Internet of Things," IJSTE - International Journal of Science Technology \& Engineering, Volume -3.Issue-09, pp. 373-377, March- 2017.

[30]R.Nagarajan,

J.Chandramohan,

S.Sathishkumar, S.Anantharaj, G.Jayakumar, M.Visnukumar and R.Viswanathan, "Implementation of PI Controller for Boost Converter in PV System," International Journal of Advanced Research in Management, Architecture, Technology and Engineering
(IJARMATE). Vol.11, Issue.XII, pp. 6-10, December. 2016.

[31]M.Elangovan, R.Yuvara, S.Sathishkumar and R.Nagarajan, "Modelling and Simulation of High Gain Hybrid Boost Converter," International Journal of Emerging Technologies in Engineering Research (IJETER), Volume 5, Issue 6, pp. 9- 14, June-2017

[32]S.Suresh, R.Nagarajan, L.Sakthivel, V.Logesh, C.Mohandass and G.Tamilselvan, "Transmission Line Fault Monitoring and Identification System by Using Internet of Things," International Journal of Advanced Engineering Research and Science (IJAERS), Vol - 4.Issue - 4, pp. 9-14, Apr- 2017.

[33]R.Nagarajan, J.Chandramohan, R.Yuvaraj, S.Sathishkumar and S.Chandran, "Performance Analysis of Synchronous SEPIC Converter for a Stand-Alone PV System," International Journal of Emerging Technologies in Engineering Research (IJETER), Vol. 5, Issue - 5, pp. 12-16, May-2017

[34]M. Sridhar, S.Sathishkumar, R.Nagarajan and R.Yuvaraj, "An Integrated High Gain Boost Resonant Converter for PV System," International Journal of Emerging Technologies in Engineering Research (IJETER), Volume 5, Issue 6, pp. 54- 59, June-2017.

[35]S.Suresh, R.Nagarajan, R.Prabhu and N.Karthick, "Energy Efficient E0 Algorithm for Wireless Transceivers," International Journal of Engineering and Computer Science (IJECS), Volume 6, Issue 7, July 2017, pp. 2198221985, DOI: 10.18535/ijecs/v6i7.15.

[36]M.Meenakshi, R.Nagarajan, R. Banupriya and M.Dharani Devi, "Stepped Multicarrier SPWM Techniques for Seven - Level Cascaded Inverter," International Journal of Emerging Technologies in Engineering Research (IJETER), Volume 5, Issue 12, pp. 43- 49, December-2017.

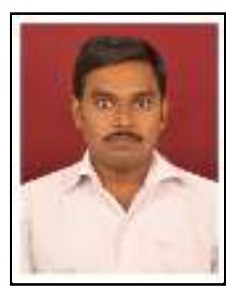

S.Sathishkumar received his B.E. in Electrical and Electronics Engineering from Anna University, Tiruchirappalli, India, in 2011. He received his M.E. in Power Electronics and Drives from Anna University, Chennai, India, in 2014. He is currently working toward his Ph.D in Power Electronics and Renewable Sources. He has worked in the industry as an Electrical Engineer. $\mathrm{He}$ is currently working as a Assistant Professor of Electrical and Electronics Engineering at 
Gnanamani College of Technology, Namakkal, Tamilnadu, India.

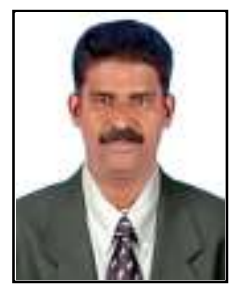

R. Nagarajan received his B.E. in Electrical and Electronics Engineering from Madurai Kamarajar University, Madurai, India, in 1997. He received his M.E. in Power Electronics and Drives from Anna University, Chennai, India, in 2008. He received his Ph.D in Electrical Engineering from Anna University, Chennai, India, in 2014. He has worked in the industry as an Electrical Engineer. He is currently working as Professor of Electrical and Electronics Engineering at Gnanamani College of Technology, Namakkal, Tamilnadu, India. His current research interest includes Power Electronics, Power System, Soft Computing Techniques and Renewable Energy Sources. 